\title{
Study the Impact Methimazole on Some Biomarkers in Patients with Hyperthyroidism
}

\author{
Ammal Esmaeel Ibrahim \\ Pharmacy College, Al-Nahrain University, Baghdad-Iraq.
}

\begin{abstract}
Methimazole used to control the symptoms of hyperthyroidism associated with Graves' disease , and to maintain patients in a euthyroid state for several years, until spontaneous remission occurs Methimazole developed in 1949, that is widely used in the treatment of hyperthyroidism. The usual starting dose is $10-30 \mathrm{mg} /$ day, given orally as a single daily dose. This study conducted during the period from July 2012 to September 2013. This study includes fourty patients with hyperthyroidism that divided into two groups: group (A) which included twenty patients treated with methimazole and group (B) which included twenty patients without treatment. All patients admitted to the Baghdad Hospital. Subject matched in age, sex and BMI. In this study: urea, creatinine, albumin, glucose were determined by enzymatic method. The results of group (A) show that were significant elevation in Albumin level while there is significant decrease in glucose level. Negative correlation was found between methimazole treatment with glucose, while there was positive correlation between Methimazole treatment and albumin. The results show a negative correlation between glucose and methimazole treatment that lead to consider methimazole suitable treatment for patient with hyperthyroidism that have family history with diabetes mellitus.
\end{abstract}

Keywords: Methimazole, urea, creatinine, albumin and glucose.

\section{Introduction}

Hyperthyroidism is a multi-system disorder caused by an increase in the amount of thyroid hormones $\left(\mathrm{T}_{3}\right.$ and $\left.\mathrm{T}_{4}\right)$ uncontrolled produced by an enlarged thyroid gland. Although the enlargement in the thyroid gland is caused by a tumor, called an adenoma, it is non-cancerous. The most common clinical signs of hyperthyroidism include weight loss, increased appetite (although some patients have decreased appetite), vomiting, increased thirst and urination, hyperactivity, and diarrhea. The high levels of thyroid hormones can cause the development of heart disease, difficulty breathing, high heart rate and arrhythmias. [1]

Methimazole used to control the symptoms of hyperthyroidism associated with Graves' disease [2], and to maintain patients in a euthyroid state for several years, until spontaneous remission occurs Methimazole is an anti-thyroid drug, developed in 1949, that is widely used in the treatment of hyperthyroidism. The usual starting dose is 10-30 mg/day, given orally as a single daily dose. [3]

Methimazole is a thioureylene antithyroid drug, which inhibits the synthesis of thyroid hormones. Methimazole (1-methylimidazole- 2-thiol) is a white, crystalline substance that is freely soluble in water. The chemical formula is C4H6N2S. Molecular weight is 114.16. [4] Methimazole belongs to a class of drugs used in the treatment of hyperthyroidism, which act by interfering with the functioning of thyroid peroxidase. The mode of action in experimental animals is inhibition of thyroid peroxidase, which decreases thyroid hormone production and increases cell proliferation by increasing the secretion of TSH. [5]

\section{Patients and Methods}

This study conducted during the period from July 2012 to September 2013. This study includes fourty patients with hyperthyroidism that divided into two groups: group (A) which included twenty patients have methimazolw as treatment and group (B) which included twenty patients without treatment. All patients admitted to the Baghdad Hospital. Subject matched in age, sex and BMI. In this study: urea, creatinine, albumin, glucose were determined by enzymatic method. Blood samples were taken from patients after having thoroughly examined. From each patient and control, five $\mathrm{ml}$ of venous blood were aspirated from a suitable vein. Blood samples 
were transferred to a plane tube to measure the levels of (urea, Creatinine, albumin glucose, T3, T4 and TSH). The non-heparinized blood in the plain tubes were left to clot and then centrifuged at 4000 round per minute (rpm) for 5 minutes to measure the parameters. Statistical analysis was performed by statisticians with the Excel 2010. Data analysis was done using independent sample t-test was used for tables with means and standard divination value of $\leq 0.05$ was used as the level of significance. Correlation coefficient used to find the correlation studied markers by using Person correlation.

\section{Results and Discussion}

Table (1)

Comparison between group (A) and group (B) for (age, high, weight, T3, T4, TSH and body mass index).

\begin{tabular}{|c|c|c|c|c|}
\hline \multicolumn{2}{|c|}{ parameters } & $\begin{array}{c}\text { Group }(A) \\
\text { Mean } \pm S D\end{array}$ & $\begin{array}{c}\text { Group (B) Mean } \pm \\
\text { SD }\end{array}$ & P-value \\
\hline Age & year & $33.307 \pm 9.871$ & $43.4 \pm 6.252$ & $<0.01$ \\
\hline High & $\mathrm{cm}$ & $160.571 \pm 6.16$ & $161.428 \pm 5.9$ & 0.760 \\
\hline Weight & $\mathrm{Kg}$ & $62.785 \pm 9.298$ & $60.214 \pm 5.503$ & 0.402 \\
\hline $\mathrm{T}_{3}$ & IIU/L & $1.307 \pm 0.443$ & $4.864 \pm 1.751$ & $<0.01$ \\
\hline $\mathrm{T}_{4}$ & IU/L & $13.761 \pm 3.291$ & $183.928 \pm 57.21$ & $<0.01$ \\
\hline TSH & IU/L & $1.441 \pm 0.881$ & $0.05 \pm 0.00$ & $<0.01$ \\
\hline BMI & $\mathrm{cm}$ & $24.331 \pm 3.219$ & $23.142 \pm 1.993$ & 0.279 \\
\hline
\end{tabular}

Table (2)

Comparison between group (A) and group (B) for (urea, Creatinine, Albumin and glucose).

\begin{tabular}{|c|c|c|c|c|}
\hline \multicolumn{2}{|c|}{ Parameters } & $\begin{array}{l}\text { Group }(A) \\
\text { Mean } \pm S D\end{array}$ & $\begin{array}{c}\text { Group }(B) \\
\text { Mean } \pm S D\end{array}$ & P-value \\
\hline Urea & $\mathrm{mg} / \mathrm{dl}$ & $22 \pm 8.786$ & $24.642 \pm 7.533$ & 0.433 \\
\hline Creatinine & $\mathrm{mg} / \mathrm{dl}$ & $0.667 \pm 0.117$ & $0.601 \pm 0.067$ & 0.09 \\
\hline Albomin & g/dl & $5.314 \pm 0.252$ & $4.621 \pm 0.340$ & $<0.01$ \\
\hline Clucose & $\mathrm{mg} / \mathrm{dl}$ & $102.21 \pm 13.54$ & $121.28 \pm 18.167$ & $<0.01$ \\
\hline
\end{tabular}

Table (3)

Correlation (r) between methimazole treatment with (urea, Creatinine, Albomin and glucose) in group (A).

\begin{tabular}{|c|c|}
\hline \hline Parameters & $(\boldsymbol{r})$ \\
\hline \hline Urea & 0.0382 \\
\hline \hline Creatinine & 0.022 \\
\hline Albomin & 0.283 \\
\hline Glucose & -0.382 \\
\hline
\end{tabular}

Table (4)

Correlation (r) between $T_{3}$ and $T_{4}$ with (urea, Creatinine and Albomin) in group $(B)$.

\begin{tabular}{|c||c||c||}
\hline Parameters & $\begin{array}{c}\boldsymbol{T}_{3} \text { hormone } \\
(\boldsymbol{r})\end{array}$ & $\begin{array}{c}\boldsymbol{T}_{4} \text { hormone } \\
(\boldsymbol{r})\end{array}$ \\
\hline \hline Urea & 0.121 & -0.099 \\
\hline \hline Creatinine & -0.168 & -0.548 \\
\hline \hline Albomin & -0.225 & -0.191 \\
\hline Glucose & 0.116 & 0.263 \\
\hline
\end{tabular}


The enfluence of hyperthyroidism on glucose was mentioned in this study in Table (2) the result show that there were significant increase in the level of glucose in Table (4) glucose is negatively correlated with T3 hormone. In patients with hyperthyroidism the activities of gluconeogenic enzymes, including glucose6-phosphatase, Phosphoenolpyrovate carboxykinase, and pyruvate carboxylase, were shown to be increased in livers and kidneys of various species. Glycogenolysis was reported to be enhanced during the early phases of hyperthyroidism, which is followed by depletion of glycogen stores in the later phases as shown by a decrease in splanchnic glucose output. [5] Glucose positively correlated with T4 (4) as result of insulin resistance. [5] while methimazole treatment is negatively correlate with glucose because this drug increase insulin receptor sensitivty so this rule of methimazole by increase the receptor sensitivity lead to decreas in glucose level.

In Table (2) show a significant increase in level of Albumin in group (A), Table (4) show that albumin was negatively correlated with $\mathrm{T} 4$ because protein degradation in liver and skeletal muscle is increased by thyroid hormones increase.[6], while in Table (3) albumin positively correlated with methimazole treatment this positive correlation may due to the modefy the effect of hyperthyrodism on liver because the level of thyroid hormones decrease with increase the time of treatment till the level of thyroid hormones retain to normal level.

Table (4) show negative correlation between Creatinine and hormone. The changes in renal parameters that follow a resolution of hyperthyroidism manifest themselves within a one month period after which ongoing measurement of renal parameters reveal relatively stable values. [8]

\section{Conclusions}

The results show a negative correlation between glucose and methimazole that lead to consider methimazole suitable treatment for hyperthyroidisms patients who have family history with diabetes mellitus. Methimazole has benefit effect on albumin synthesis. There is no correlation between methimazole with urea and Creatinine so there is no effect of methimazole on renal function.

\section{References}

[1] Gattineni J, Sas D, Dagan A, Dwarakanath V, Baum M. "Report of the DGAC on the Dietary" Guidelines for Americans, 68(133), 41433-41506, 2010.

[2] Khoshniat, M., Bahrainian, M. and Hedayati, M. "Thyroid function and intellectual development of infants nursed by mothers taking methimazole" J. clin. Endocrinol. Metab.85, 3233-3238, 2006.

[3] Abraham P, Avenell A, Watson WA, Park CM, Bevan JS. "Antithyroid drug regimen for treating Graves" hyperthyroidism. Cochrane Database Syst Rev 2004; 2:CD003420.

[4] Yavuz DG, Yuksel M, Deyneli O, Ozen Y, Aydin H, Akalin S. "Association of serum paraoxonase activity with insulin sensitivity and oxidative stress in hyperthyroid and TSH suppressed nodular goitre patients." Clin Endocrinol .61(4), 515-521, 2004

[5] Jeffrey R., Rhoda H., Hossein Gharib, James V., Irwin Klein, "clinical practice guidelines for hypothyroidism in adults: cosponsored by the american association of clinical endocrinologists and the american thyroid association" endocrine practice, 18(6), 989-1027, 2012.

[6] Liberopoulos E, Miltiadous G, Elisaf M, "Impressive lipid changes following hypolipidaemic drug administration can unveil subclinical hyperthyroidism". Diabetes Obes Metab, 3,97-8, 2004.

[7] Rizos, C.V., Elisaf M.S and Liberopoulos E.N "Effects of Thyroid Dysfunction on Lipid Profile." Open Cardiovascular Medicine Journal, 5,76-84, 2011.

[8] Jyothsna Gattineni, David Sas, Amit Dagan, Vangipuram Dwarakanath, and Michel Baum. "Effect of thyroid hormone on the postnatal renal expression of NHE8." American Journal of Physiology. Renal Physiology, 294(1), 198-204, 2008. 


\section{- الخلاصة}

ميثيمازول يستخدم للسيطرة على أعراض فرط نشاط الدرق

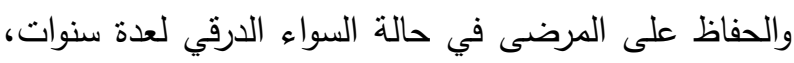

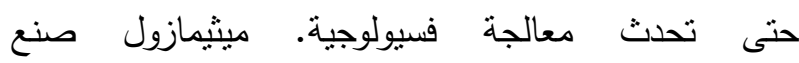
في عام 9 9 19، والذي يستخدم على نطاق واسع في فئس علاج فرط نشاط الدرق. الجرعة المعتادة في البداية هي

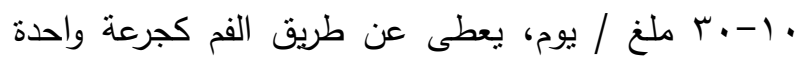

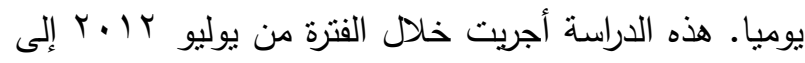

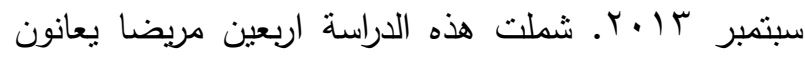
من فرط الغدة الدرقية وقسم المرضى الى مجموعنين:

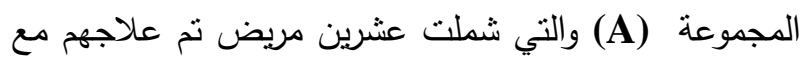
ميثمازول و المجموعة (B) والتي شملت عشرين المرضى دون علاج. تم جمع النماذج من المرضى في مستشفى المانى بغداد. نم قياس: اليوريا، والكرياتينين، الزلال، ونم تحديد نسبة

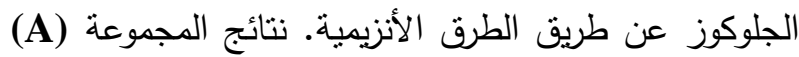

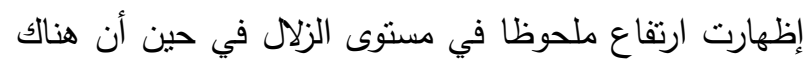

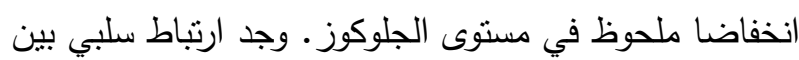

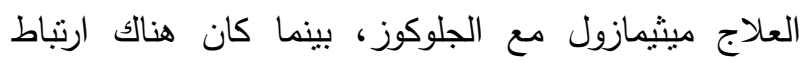

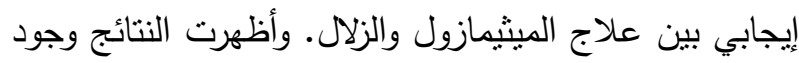
علاقة عكسية بين نسبة الجلوكوز والعلاج ميثيمازول التي تؤدي إلى النظر ميثيمازول علاج مناسب للمريض مع فرط الغدة الدرقية الذين لديهم تاريخ عائلي مع مرض السكرين منابي. 